\title{
Effects of cortisol implants on the susceptibility and the histopathology of the responses of naive coho salmon Oncorhynchus kisutch to experimental infection with Lepeophtheirus salmonis (Copepoda: Caligidae)
}

\author{
S. C. Johnson ${ }^{1, *}$, L. J. Albright ${ }^{2}$ \\ ${ }^{1}$ Department of Fisheries and Oceans, Biological Sciences Branch, Pacific Biological Station, Nanaimo, British Columbia, \\ Canada V9R 5K6 \\ ${ }^{2}$ Institute for Aquaculture Research, Simon Fraser University, Burnaby, British Columbia, Canada V5A 1S6
}

\begin{abstract}
The effects of hydrocortisol implants on the susceptibility of naive coho salmon Oncorhynchus kisutch to infection with the economically important marine ectoparasitic copepod Lepeophtheirus salmonis was investigated under laboratory conditions. Cortisol-implanted coho salmon were more susceptible to infection than the control coho salmon. Copepods were lost from the gills of the control coho salmon by $10 \mathrm{~d}$ post-infection, and only a few remained on the body and fins at $20 \mathrm{~d}$ post-infection. Copepods were retained on the gills, fins and body of the cortisol-implanted coho salmon over the $20 \mathrm{~d}$ studied. Histological sections of control coho gills and fins revealed well developed epithelial hyperplasias and inflammatory responses to the presence of $L$. salmonis. The magnitude of the inflammatory response and the development of epithelial hyperplasia was suppressed in the cortisol-implanted coho. These data support the hypothesis that non-specific host defence mechanisms are important in resistance of coho salmon to infection with $L$. salmonis.
\end{abstract}

\section{INTRODUCTION}

Lepeophtheirus salmonis is a common marine ectoparasitic copepod of wild and pen-reared salmonids throughout the northern hemisphere (Kabata 1979, 1988, Wootten et al. 1982). It has a direct life cycle consisting of 5 phases and 10 stages. These include 2 free-swimming naupliar stages, 1 free-swimming infectious copepodid stage, 4 attached chalimus stages, 2 preadult stages and an adult stage (Johnson \& Albright 1991a). Attached copepodids, chalimus larvae, preadults and adults feed on host mucus, skin and blood (Kabata 1974, Brandal et al. 1976). When abundant, $L$. salmonis causes serious disease which is characterized by extensive areas of skin erosion and hemorrhaging on the head and back, and a distinct

- Addressee for correspondence area of erosion and sub-epidermal hemorrhages in the perianal region (Brandal \& Egidius 1979, Wootten et al. 1982).

Johnson \& Albright (1992) demonstrated that naive coho salmon Oncorhynchus kisutch are more resistant than naive chinook Oncorhynchus tshawytscha or naive Atlantic salmon Salmo salar to experimental infection with Lepeophtheirus salmonis. Histological examination of attachment and feeding sites on the gills of coho salmon revealed a well developed inflammatory response as early as $1 \mathrm{~d}$ post-infection. Copepods were eliminated from the gills of coho salmon from $10 \mathrm{~d}$ post-infection onwards. Histological examination of infected fins from coho salmon revealed variable epidermal erosion and inflammation of the dermis up to $5 \mathrm{~d}$ post-infection. At 10,15 and $20 \mathrm{~d}$ post-infection the lesions were characterized by well developed epithelial hyperplasias and intense inflammatory responses. 
In the initial phases of the infection, reduction in the intensity of Lepeophtheirus salmonis on coho salmon is thought to be caused by non-specific host responses, including epithelial hyperplasia, soluble or cellular factors of the inflammatory response, and/or possibly serum enzymes or other proteins. Specific humoral or cellular factors may be important in later stages of the infection.

Implantation of corticosteroids in fish has been shown to increase their susceptibility to a wide variety of parasitic diseases (reviewed in Pickering 1987; Kent \& Hedrick 1987, Nazrul Islam \& Woo 1991). In fish, the implantation of hydrocortisol has been demonstrated to inhibit inflammatory responses, inhibit phagocytosis, suppress both humoral and cellular immune responses, and retard the wound healing process (Kent \& Hedrick 1987, Pickering 1987, Roubal \& Bullock 1988, Saad 1988, Nazrul Islam \& Woo 1991).

In this study, naive coho salmon were treated with cortisol implants to determine the effects of immunosuppression on their resistance to experimental infection with Lepeophtheirus salmonis. The effects of cortisol implantation on the histopathology of attachment and feeding sites of $L$. salmonis on the gills and fins are also described.

\section{MATERIALS AND METHODS}

Parasite exposure, fish maintenance, and examination. Sample fish ( 45 cortisol-implanted and 45 control) were introduced into separate $500 \mathrm{l}$ fiberglass tanks and allowed to acclimate for $1 \mathrm{wk}$. The cortisolimplanted and adipose clipped fish were then transferred into the tank containing the control fish and both groups of fish were exposed for $24 \mathrm{~h}$ to ca 4000 newly molted copepodid larvae. The methods for obtaining the copepodids and for carrying out the infections are given in Johnson \& Albright (1991b). Prior to copepodid exposure and at 10 and 20 d postinfection, plasma samples were collected from 5 fish from each of the control and cortisol-implanted groups for cortisol analysis. At sampling, the fish were anesthetized with a high dose of MS-222 (tricaine methanesulfonate), had their caudal fins severed, and their blood was collected in $5 \mathrm{ml}$ heparinized tubes for plasma cortisol analysis.

Fish were maintained in flowing sea water with a temperature of 10.7 to $12.6^{\circ} \mathrm{C}$ (mean: $11.5^{\circ} \mathrm{C}$ ) and ambient salinity (29 to $31 \%$ ). All fish were fed a commercial dry pellet feed at $1 \%$ body wt $d^{-1}$. At $1,3,5$, 10,15 and 20 d post-infection, 6 of each of the cortisolimplanted and control fish were rapidly killed with MS-222. The fork length and wet weight was determined for each fish. Both the anesthetic bath and the body surfaces were examined for copepods and the distribution of the copepods on the fish was noted. The number of copepods present was corrected to a standard wet body wt to compensate for differences in size among hosts.

Intensity data were $\log (x+1)$ transformed and differences in copepod intensity (number of parasites per infected host) investigated by analysis of variance (ANOVA) procedures. Comparisons of copepod intensity for each treatment over time were made using Scheffé's tests (Zar 1984). Comparisons of copepod intensity between treatments at each sampling period were made using $t$-tests.

Cortisol administration and analysis. Coconut oil was pasteurized at $70^{\circ} \mathrm{C}$, cooled to $30^{\circ} \mathrm{C}$, and mixed with hydrocortisol (Sigma No. H-4001) to yield a final concentration of $127 \mathrm{mg}$ hydrocortisol $\mathrm{ml}^{-1}$ oil. A group of 45 naive coho were anesthetized with MS-222, adipose fin-clipped, and injected intraperitoneally with $0.2 \mathrm{ml}$ of cortisol solution per fish. This resulted in an implant of ca $0.5 \mathrm{mg}$ hydrocortisol $\mathrm{g}^{-1}$ of fish based on an average fish wt of $51.0 \mathrm{~g}$. A second group of 45 naive coho of the same size were selected as controls. These fish were anesthetized but not injected.

To determine plasma cortisol levels blood samples were spun at $6500 \mathrm{rpm}(1900 \times \mathrm{g})$ for $5 \mathrm{~min}$, and the resulting plasma was transferred to sterile cryotubes. Plasma samples were stored frozen at $-70^{\circ} \mathrm{C}$ and their cortisol levels determined using a radioimmunoassay technique (Sumpter \& Donaldson 1986).

Histology. Tissues for examination by light microscopy were fixed in Davidson's solution and dehydrated through to $100 \%$ alcohol. Tissues were either wax-embedded, cut to a thickness of $5 \mu \mathrm{m}$, and stained with hematoxlylin and eosin, or they were embedded in JB4 plastic resin, cut to a thickness of 1 to $2 \mu \mathrm{m}$, and stained with Lee's stain (methylene blue and basic fuschin).

\section{RESULTS}

\section{Intensity of infection}

The intensity of Lepeophtheirus salmonis on the cortisol-implanted and control groups over time is presented in Fig. 1. The intensities of infection for both the cortisol-implanted and control groups were significantly different over time (1-way ANOVA; cortisolimplanted. $p<0.001$; control: $p<0.001$ ). The results of multiple range tests (Scheffé's test; $p<0.05$ ) over time showed the control group to have significantly fewer copepods at 20 d post-infection when compared to 1, 3, 5 and $10 \mathrm{~d}$ post-infection, and the cortisol-implanted group to have significantly fewer parasites at $20 \mathrm{~d}$ post- 


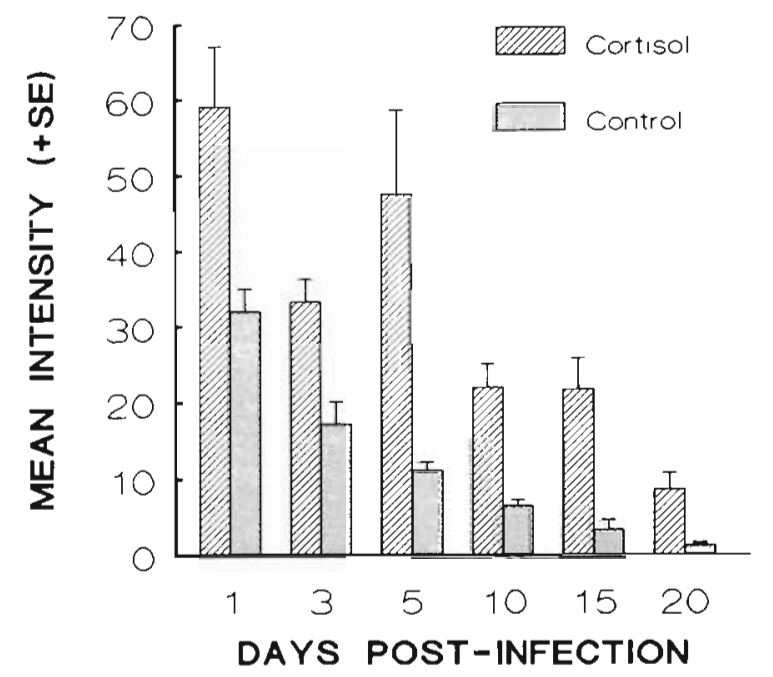

Fig. 1 Lepeophtheirus salmonis infecting Oncorhynchus kisutch. Mean (+ SE) intensity on naive cortisol-implanted and naive control coho salmon at various times post-infection. Fish were maintained at 10.7 to $12.6^{\circ} \mathrm{C}$ and ambient salinity (29 to $31 \%$ )

infection when compared to $1,3,5,10$ and $15 \mathrm{~d}$ postinfection (Fig. 1). At each sampling time, significantly fewer copepods were present on the control group than on the cortisol-implanted group $(t$-test; $p<0.05)$.

\section{Distribution}

The highest percentage of copepods recovered from the control group at all sampling periods except at $20 \mathrm{~d}$ post-infection was from the fins (Fig. 2). The percent-

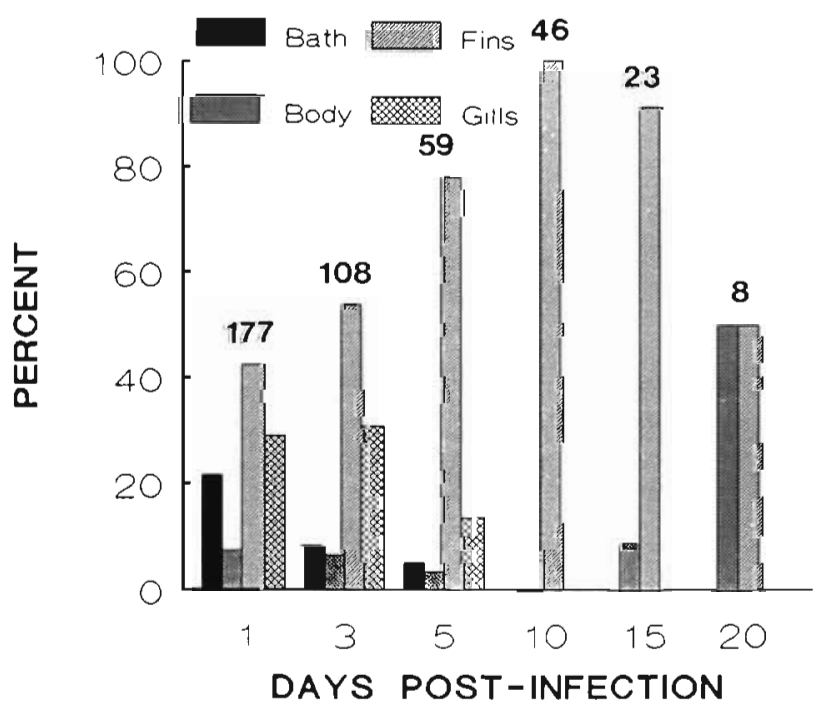

Fig. 2. Lepeophtheirus salmonis infecting Oncorhynchus kisutch. Distribution on naive control coho salmon; conditions as in Fig. 1 Values above bars are the total number of copepods collected age of copepods recovered from the anesthetic bath decreased from ca $21 \%$ to $0 \%$ by $10 \mathrm{~d}$ post-infection. Of the copepods attached to the host at 1 and $3 \mathrm{~d}$ postinfection, ca $30 \%$ were collected from the gills. The percentage of copepods on the gills declined to $0 \%$ by $10 \mathrm{~d}$ post-infection. Small numbers of copepods were recovered from the body surfaces at 1, 3 and 5 d postinfection. At 15 and $20 \mathrm{~d}$ post-infection the percentages on the body surfaces increased due to molting to the preadult stage and shifting of their attachment sites.

The highest percentages of copepods recovered from the cortisol-implanted group were from the gills and fins at all sampling periods except $20 \mathrm{~d}$ postinfection (Fig. 3). Small percentages of copepods were recovered from the anesthetic bath up to $5 \mathrm{~d}$ postinfection, and from the body surfaces from 1 to $10 \mathrm{~d}$ post-infection. As with the control fish the percentages on the body surface increased at 15 and $20 \mathrm{~d}$ postinfection due to molting to the preadult stage and shifting of their attachment sites.

\section{Mortality and gross morphology of the lesions}

Of the cortisol-implanted fish, $16 \%$ died between 9 and $17 \mathrm{~d}$ post-infection. These fish showed severe erosion of the snout and fins caused by heavy infections of filamentous bacteria (seawater 'myxobacteriosis'). From $5 \mathrm{~d}$ post-infection onwards all of the cortisolimplanted fish were lethargic and showed varying amounts of erosion of the snout and/or fins. No mortality occurred in the control group and no body and/or fin erosion was evident in the control fish sampled.

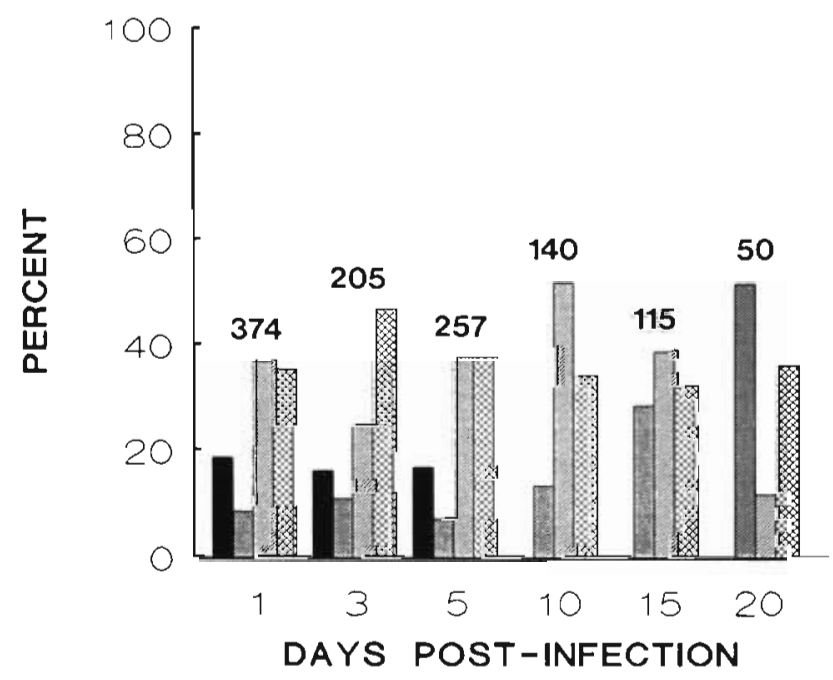

Fig. 3. Lepeophtheirus salmonis infecting Oncorhynchus kisutch. Distribution on naive cortisol-implanted coho salmon; conditions as in Fig. 1. Values above bars are the total number of copepods collected 
Table 1. Lepeophtheirus salmonis infecting Oncorhynchus kisutch. Ranges of plasma cortisol levels $\left(\mathrm{ng} \mathrm{ml} \mathrm{ml}^{-1}\right.$ ) in naive coho salmon given intraperitoneal implants of hydrocortisol, pre-infection and after infection. All ranges are based on samples of 5 fish

\begin{tabular}{|lcr|}
\hline & Control & Cortisol-treated \\
\hline Pre-infection & $14.2-77.5$ & $569.1->819.3^{\circ}$ \\
10d post-infection & $11.7-48.7$ & $355.8->706.7^{\circ}$ \\
20 d post-infection & $10.0-26.0$ & $192.4->823.6^{\circ}$ \\
aValues above the detection limit of the radioimmunoassay
\end{tabular}

Cortisol-treated fish had much higher plasma cortisol levels than the control fish in all samples (Table 1).

Grossly, the gills of both the control and cortisolimplanted groups at 1, 3 and $5 \mathrm{~d}$ post-infection showed variable amounts of erosion and clubbing of the filament tips. From 10 to $20 \mathrm{~d}$ post-infection the gills of the cortisol-implanted group showed progressive erosion of the filament tips, clubbing, and fusion of the secondary lamellae.

Gross examination of 45 lesions on the fins of the control group over the period of 10 to $20 \mathrm{~d}$ postinfection revealed areas of proliferating host tissue immediately adjacent to or surrounding the copepods. Gross examination of 45 lesions on the fins of the cortisol-implanted group over the same period revealed no tissue response to the presence of the copepods.

\section{Gill histology}

At 1 and $5 \mathrm{~d}$ post-infection, attachment and feeding sites on the gills of control coho salmon were characterized by variable amounts of erosion of the epithelium, hemorrhage, and inflammation (Fig. $4 \mathrm{~A}$ to D). In some cases minor epithelial hyperplasia resulted in fusion of the secondary lamellae near the tips of the primary lamellae. In severe cases the central rods of the primary lamellae were exposed. The inflammatory infiltrate consisted of abundant neutrophils and a few lymphocytes (Fig. 4B, D). No secondary infection of the gills was observed over this period.

At 1,5 and $10 \mathrm{~d}$ post-infection, attachment and feeding sites on the gills of cortisol-implanted coho salmon were characterized by variable amounts of erosion of the epithelium and underlying tissues, hemorrhage, and mild inflammatory responses (Fig. 5A, B). In most instances the inflammatory response was limited to the presence of scattered inflammatory cells (mostly neutrophils). In some sections a small amount of epithelial hyperplasia and fusion of the secondary lamellae was evident. At 1 and 5 d post-infection, both the intensities of the inflammatory responses and the extent of epithelial hyperplasias appeared to be less than those seen in the control group. Examination of attachment and feeding sites at 15 and $20 \mathrm{~d}$ postinfection revealed increased numbers of primary lamellae affected, well developed inflammatory responses, and increased levels of epithelial hyperplasia and fusion of the secondary gill lamellae (Fig. 5C, D). Hemorrhage in the tissues at the site of parasite attachment was a common feature of the lesions over this period. The inflammatory infiltrate consisted primarily of neutrophils, but lymphocytes were also present (Fig. 5D). Secondary infection of the gill lesions by filamentous bacteria occurred in some sections.

\section{Fin histology}

Over the period of 1 to $5 \mathrm{~d}$ post-infection, attachment and feeding sites on fins of both the control and cortisol-implanted groups were characterized by variable amounts of epidermal erosion and necrosis (Fig. 6A, B). Over this period the severity of the lesions was highly variable within treatment groups with later lesions not necessarily more severe than earlier lesions. Mild inflammation of the dermis occurred in the control group as early as $1 \mathrm{~d}$ post-infection (Fig. 6A). Neutrophils were the predominant cells at these sites of inflammation. No inflammation was observed in the cortisol-implanted group over this period.

At 10,15 and $20 \mathrm{~d}$ post infection, attachment and feeding sites on the fins of the control group were characterized by well developed epithelial hyperplasias (Figs. 6C to $7 \mathrm{~B}$ ), which in severe cases resulted in the complete encapsulation of the copepod. In cases of encapsulation the spaces surrounding the copepod were filled with a mixed inflammatory infiltrate (neutrophils, macrophages, and a few lymphocytes), and necrotic tissue. Intense inflammation of the dermis occurred in all control samples over this period. The inflammatory infiltrate consisted of abundant neutrophils and macrophages and a few lymphocytes (Figs. 6D \& 7B).

With exception of 2 samples that showed mild epithelial hyperplasia, hyperplasia was not seen in the cortisol-implanted group over the period of 10 to $20 \mathrm{~d}$ post-infection (Fig 7C, D). Mild inflammation of the dermis occurred in all samples collected at 15 and $20 \mathrm{~d}$ post-infection. The inflammatory infiltrate consisted of neutrophils, some macrophages, and some lymphocytes (Fig. 8)

\section{DISCUSSION}

The level of hydrocortisol implanted in coho salmon in this investigation is higher than the level of $0.01 \mathrm{mg}$ 


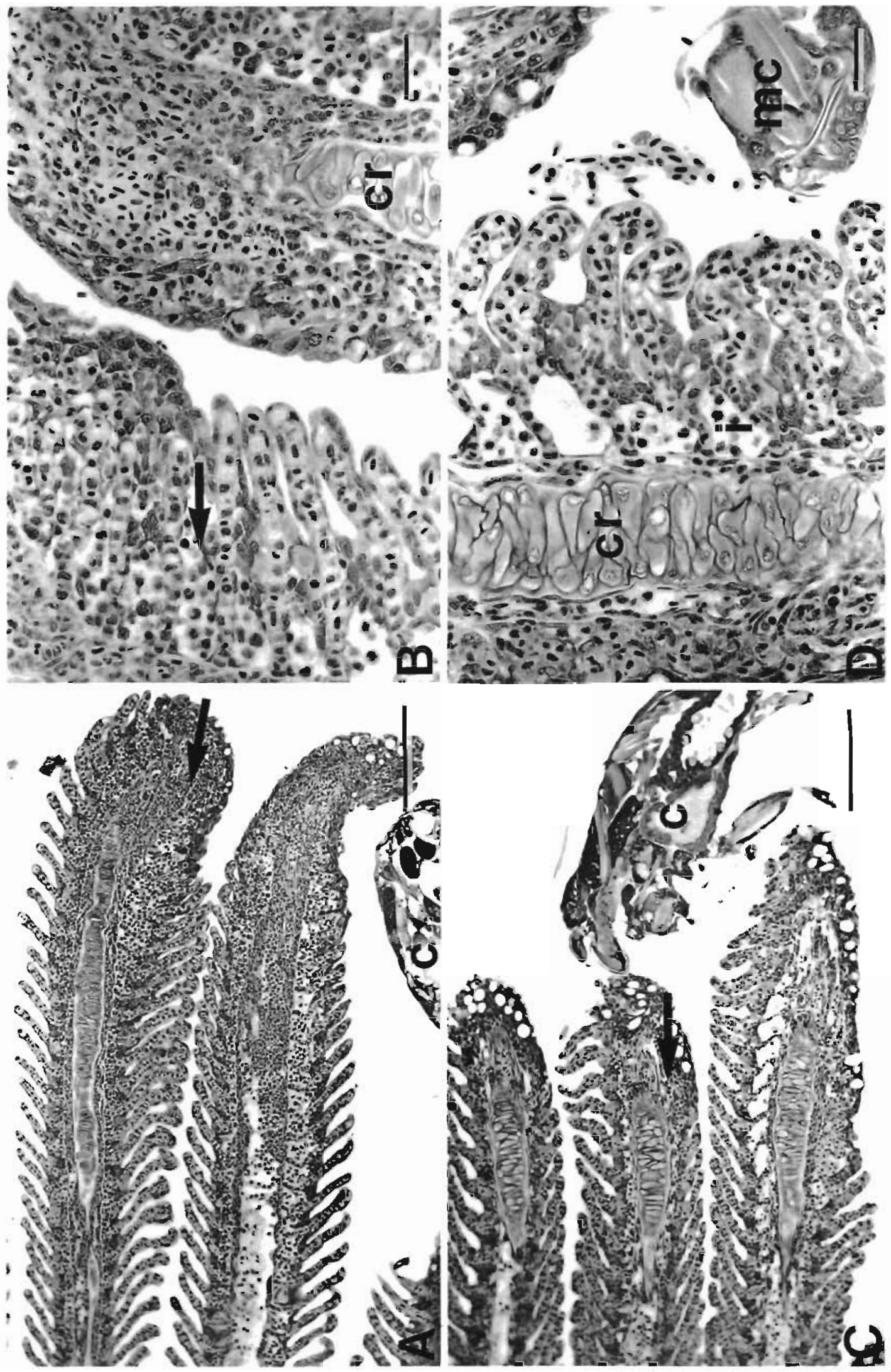

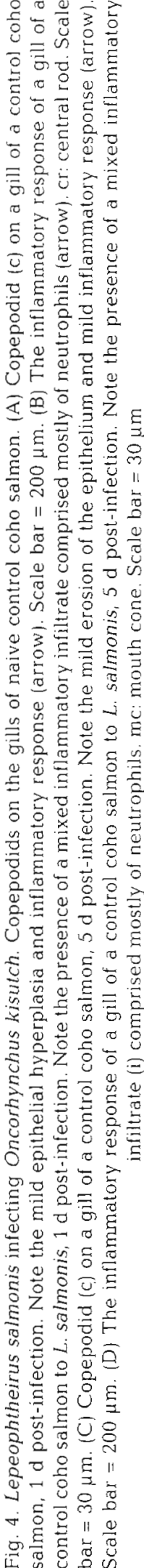




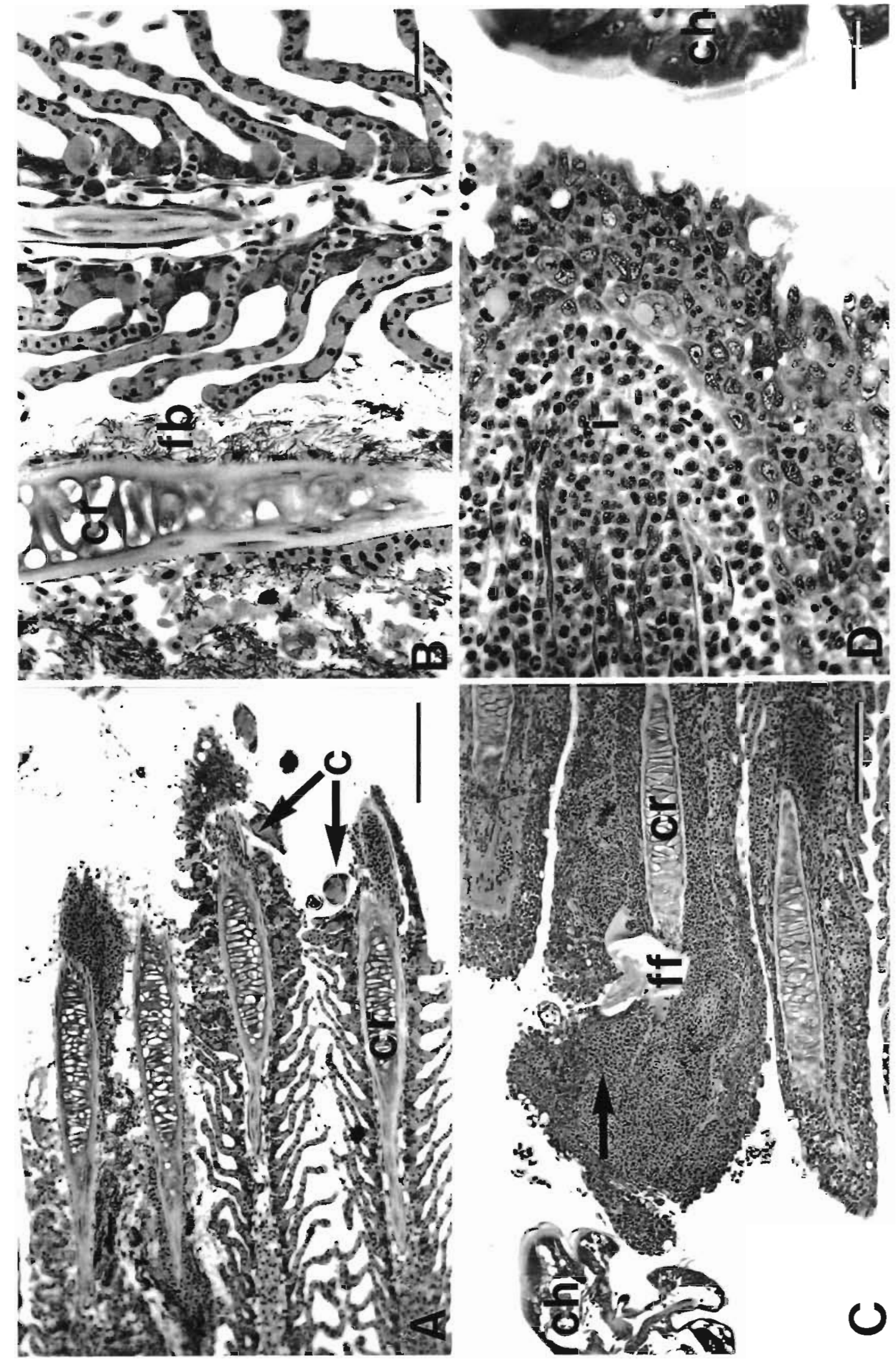

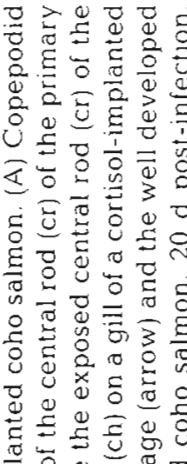

잉

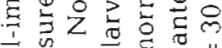

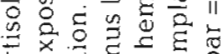

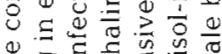

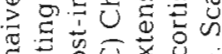

不

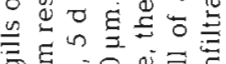

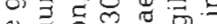

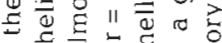

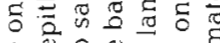

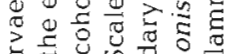

응

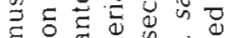

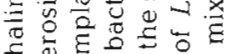

5

(5)

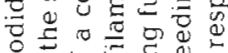

क्ष 0

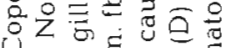

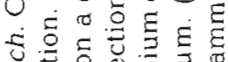

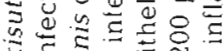

更

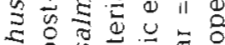

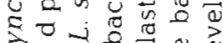

눙

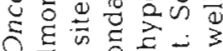

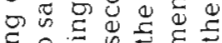

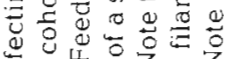

制 $z-z$

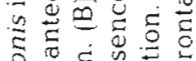

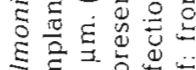

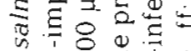

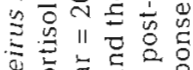

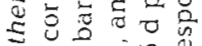

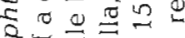

\&

可

i

过可过 


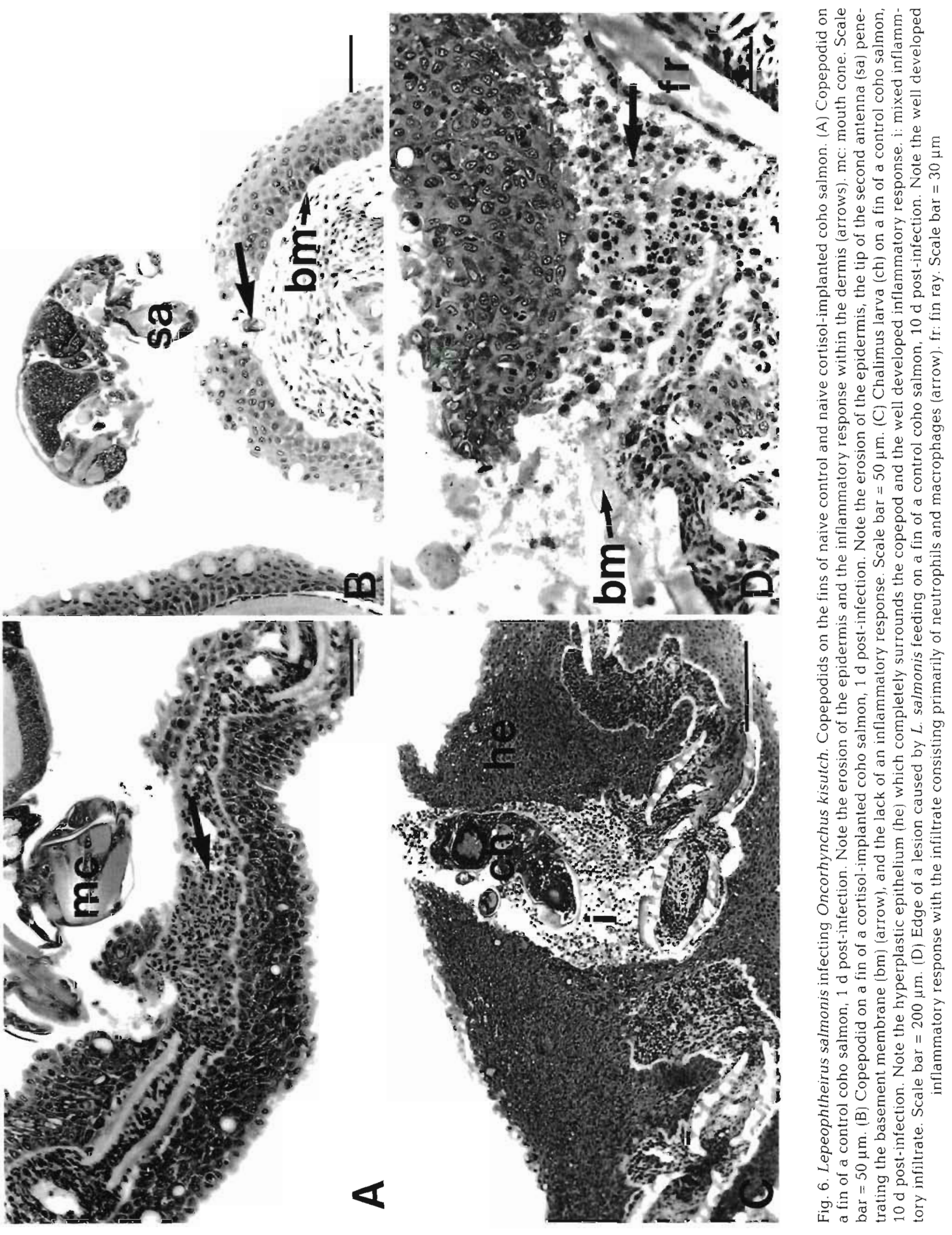



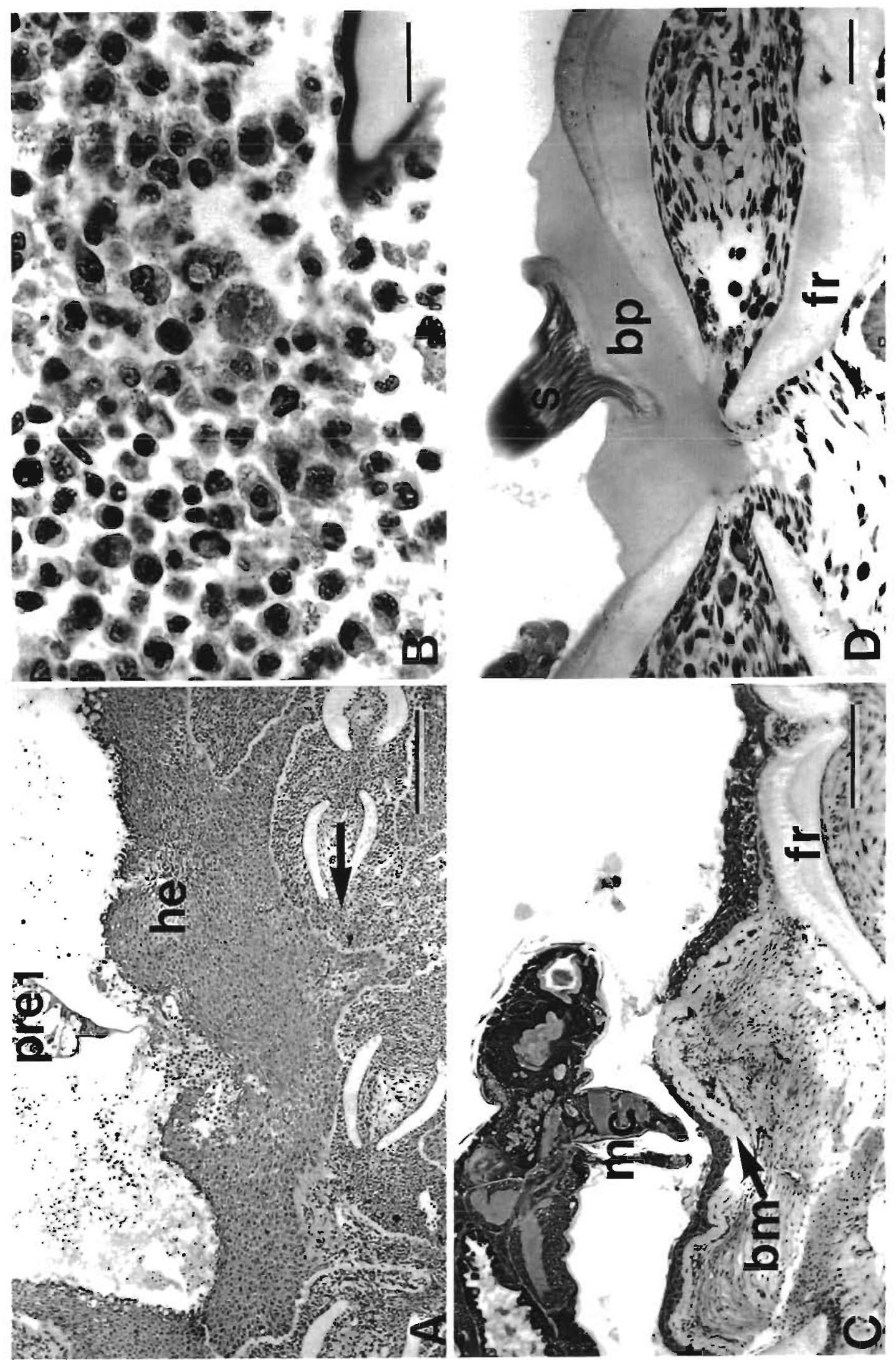

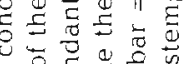

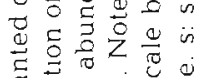

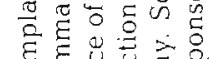

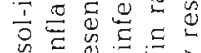

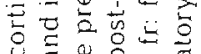

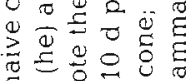

을

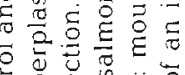

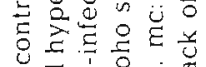

Q

元焉呵

훙웜용

怘宫焉

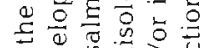

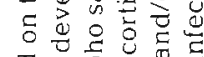

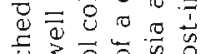

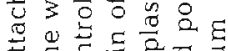

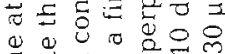

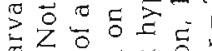

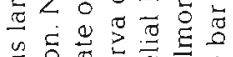

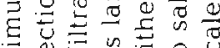

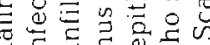

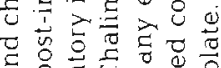

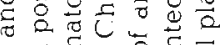

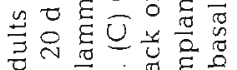

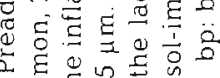

矛芯吉

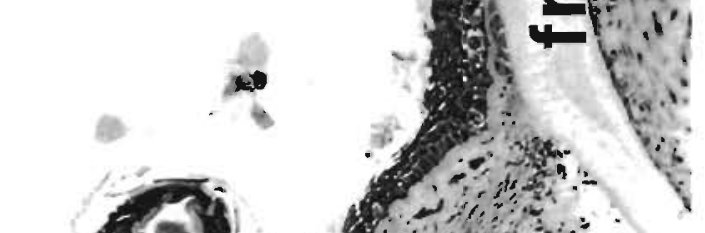

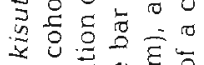

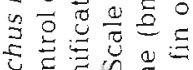

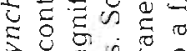

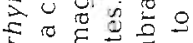

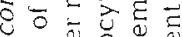

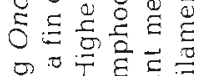

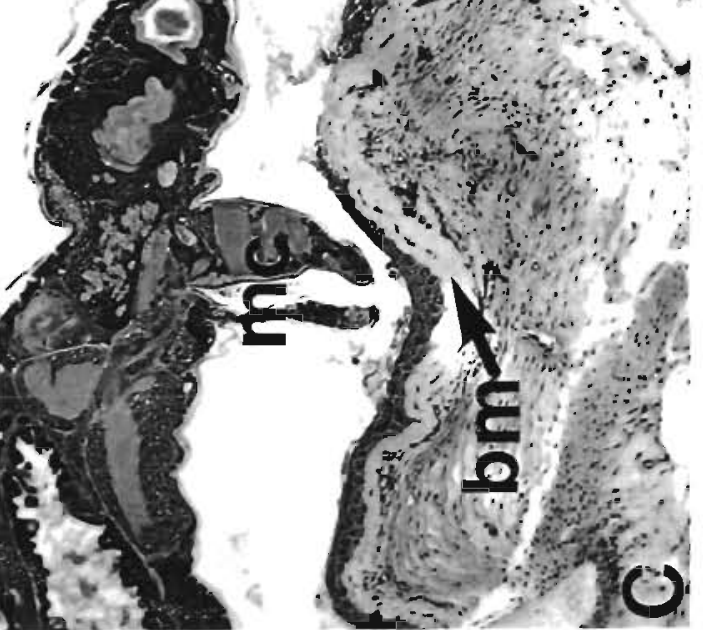

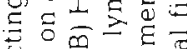

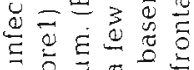

气

ह 융 11 is

क 00

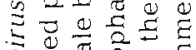

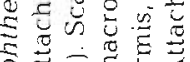

\&这的造

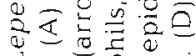

$\therefore \stackrel{\circ}{\circ}$

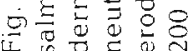


Fig. 8. Lepeophyheirus salmonis infecting Oncorhynchus kisutch. Feeding site of a chalimus larva on a fin of a naive cortisol-implanted coho salmon, $20 \mathrm{~d}$ post-infection. Note the erosion of the epidermis, the exposed fin rays ( $\mathrm{fr}$ ), the mild inflammatory response, and the secondary bacterial infection. $f b$ : filamentous bacteria. Scale bar $=30 \mu \mathrm{m}$

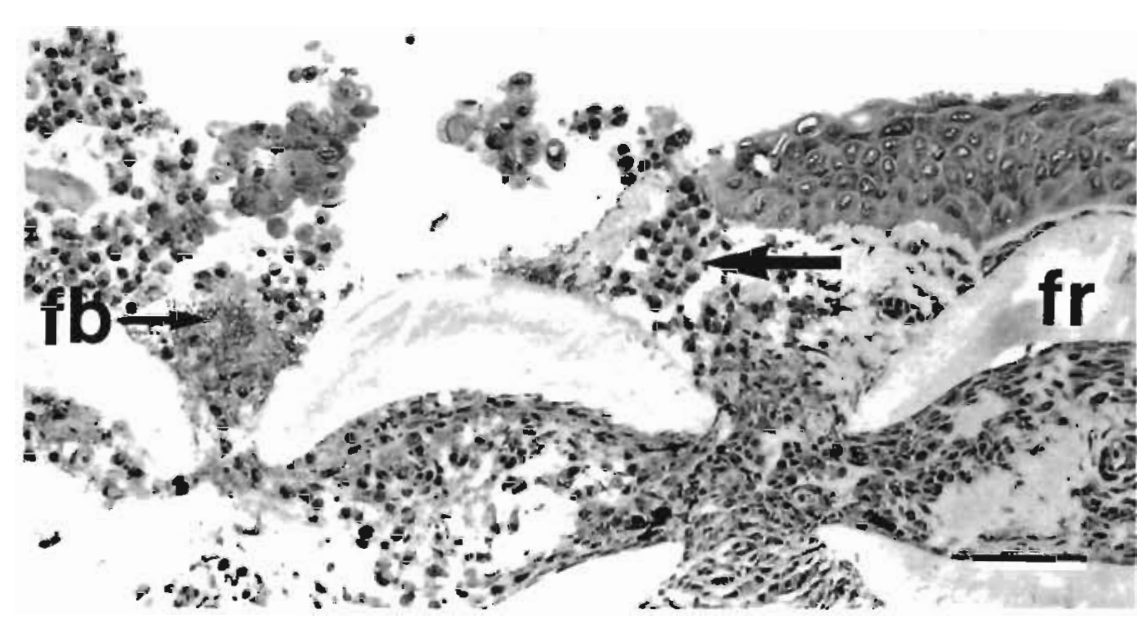

cortisol $\mathrm{g}^{-1}$ body wt which has been demonstrated to elevate blood cortisol levels and cause chronic immunosuppression in coho salmon (Maule et al. 1987). Levels of $0.5 \mathrm{mg}$ cortisol $\mathrm{g}^{-1}$ body wt and less have also been demonstrated to cause chronic immunosuppression of both rainbow Oncorhynchus mykiss and brown trout Salmo trutta (Pickering \& Duston 1983, Pickering \& Pottinger 1985, Kent \& Hedrick 1987. Woo et al. 1987). That the level of hydrocortisol implanted was sufficient to cause chronic immunosuppression is shown by the high prevalence of snout and fin erosion caused by secondary bacterial infections, as well as $16 \%$ mortality in the cortisol-implanted group.

Significantly higher intensity of Lepeoptheirus salmonis on the cortisol-implanted group compared to that on the control group on each day sampled demonstrates that treatment with cortisol predisposed naive coho salmon to infection with $L$. salmonis. This is the first report of a corticosteroid treatment affecting the susceptibility of fish to infection by parasitic copepods. Administration of corticosteroids to fish has been demonstrated to enhance the establishment and increase the intensity of other parasitic infections and to make resistant hosts susceptible to parasitic infection. Robertson et al. (1963) reported that rainbow trout given intraperitoneal implants of cortisol and cholesterol developed heavy infections of the ciliate Ichthyophthirius multifiliis. Implantation of cortisol in rainbow trout resulted in increased numbers of the PKX myxosporean, and enhanced the ability of this myxosporean to reach the sporogonic stage (Kent \& Hedrick 1987). Cortisol-implanted rainbow trout also had a significantly higher parasitaemia, higher mortality, and lower antibody titres than control fish when challenged with the hemoflagellate Cryptobia salmositica (Woo et al. 1987). Immunized juvenile mirror carp Cyprinus carpio that were injected with the corticosteroid triamcinolone acetonide suffered $100 \%$ mortality compared to $0 \%$ in the immunized control groups after exposure to I. multifiliis (Houghton \& Matthews 1986).

In the present experiment, implantation of hydrocortisol reduced the inflammatory response of both the gills and fins of naive coho salmon to Lepeophtheirus salmonis. Administration of corticosteriods has been previously reported to suppress both chemically and surgically induced inflammation in rainbow trout (Weinreb 1958), to suppress the inflammatory response of interstitial kidney tissue of rainbow trout to the PKX myxosporean (Kent \& Hedrick 1987), and to cause significant reductions in the extent of inflammatory cell infiltration (mostly neutrophils and macrophages) in the peritoneum of plaice Pleuronectes platessa (MacAurther et al. 1984). Fletcher (1986) demonstrated in vitro that cortisol at concentrations normally found in stressed plaice significantly reduced the migration of neutrophils derived from the peritoneum.

Suppression of epithelial hyperplasia by cortisol treatment as observed in the present study has not been previously reported. Although hyperplasia is a common response of the fish epidermis when exposed to a wide variety of agents such as chemical pollutants, hormonal stimuli, and bacteria or viruses (see Roberts 1978), the mechanisms by which it is controlled are not understood. Cortisol may limit epithelial hyperplasia by affecting the mitotic activity of the fish epidermis. We know of no data on the effects of corticosteroids on mitotic activity in the fish epidermis. In the amphibian Rana pipiens, an inverse relationship between epidermal mitotic rate and the level of plasma corticosteriods 
has been reported (Garcia-Arce \& Mizell 1972). Hydrocortisone is also known to inhibit mammalian epidermal healing by retarding mitotic activity (Pickering 1987).

Epithelial hyperplasia is commonly reported in association with sites of chronic inflammation in fish. This association suggests that components of the nonspecific and/or specific humoral immune system may be important in the initiation and/or maintenance of hyperplasia. If this is the case cortisol may limit epithelial hyperplasia through its suppression of the nonspecific and specific humoral systems.

In the cortisol-implanted group the percentage of copepods on the gills remained approximately constant while the percentage on the fins declined and the percentage on the body increased towards the end of the experiment. These results suggest that Lepeophtheirus salmonis developed to the preadult stage faster on the fins than on the gills. Johnson \& Albright (1992) reported a slower development rate of $L$. salmonis on the gills than on the fins of Atlantic salmon.

The level of cortisol implanted in this study elevated plasma cortisol levels beyond the normal physiological range for coho salmon (Advella et al. 1991). Therefore, the results cannot be taken as proof that stress or disease-induced elevations of plasma cortisol would lead to increased susceptibility of naive coho to infection with Lepeophtheirus salmonis. Further study is required to determine if similar results can be obtained with plasma cortisol levels that mimic those seen in stressed or diseased coho salmon.

In conclusion, we have shown that implantation of hydrocortisol increased the susceptibility of naive coho salmon to infection with Lepeophtheirus salmonis. Non-specific host defence mechanisms, including the magnitude of the inflammatory response and the development of epithelial hyperplasia, were suppressed in the cortisol-implanted group. These mechanisms appear to be responsible for the low susceptibility of naive coho salmon to infection with $L$. salmonis. The mechanism by which cortisol suppresses epithelial hyperplasia remains to be elucidated.

Acknowledgements. We thank Dr Leo Margolis for critically reviewing this manuscript and Helen Dye for conducting the cortisol analysis. This research was funded by the Department of Fisheries and Ocean's Biological Sciences Branch, Pacific Region, and a by a Natural Sciences and Engineering Research Council of Canada Operating Grant to L.J.A. S.C.J. was supported by a British Columbia Science Council GREAT scholarship

\section{LITERATURE CITED}

Advella, M. A., Schreck, C. B., Prunet, P. (1991). Plasma prolactin and cortisol concentrations of stressed coho salmon,
Oncorhynchus kisutch, in fresh water or salt water. Gen. comp. Endocrinol. 81. 21-27

Brandal, P. O., Egidius, E. (1979). Treatment of salmon lice (Lepeophtheirus salmonis Krøyer, 1838) with Neguvon ${ }^{R}$ description of method and equipment. Aquaculture 18: $183-188$

Brandal, P. O., Egidius, E., Romslo, I. (1976). Host blood: a major food component for the parasitic copepod Lepeophtheirus salmonis Kroyer, 1838 (Crustacea: Caligidae). Norw. J. Zool. 24: 341-343

Fletcher, T. C. (1986). Modulation of nonspecific host defenses in fish. Vet. Immunol. Immunopathol. 12: 59-67

Garcia-Arce, H., Mizell, S. (1972). Mitotic activity in dorsal epidermis of Rana pipiens. Comp. Biochem. Physiol. 42A: 501-509

Houghton, G., Matthews, R. A. (1986). Immunosuppression of carp (Cyprinus carpio L.) to ichthyophthiriasis using the corticosteroid triamcinolone acetonide. Vet. Immunol. Immunopathol. 12: 413-419

Johnson, S. C., Albright, L. J. (1991a). The developmental stages of Lepeophtheirus salmonis (Krøyer, 1837) (Copepoda: Caligidae) Can. J. Zool. 69: $929-950$

Johnson, S. C., Albright, L. J. (1991b) Development, growth, and survival of Lepeophtheirus salmonis (Copepoda: Caligidae) under laboratory conditions. J. mar. biol. Ass. U.K. $71: 425-436$

Johnson, S. C., Albright, L. J. (1992). Comparative susceptibility and histopathology of the host response of naive Atlantic, chinook, and coho salmon to experimental infection with Lepeophtheirus salmonis (Copepoda: Caligidae). Dis. aquat. Org. 14: 179-193

Kabata, Z. (1974). Mouth and mode of feeding of Caligidae (Copepoda), parasites of fishes, as determined by light and scanning electron microscopy. J. Fish. Res. Bd Can. 31. $1583-1588$

Kabata, Z. (1979). Parasitic Copepoda of British fishes. The Ray Society, London

Kabata, Z. (1988). Copepoda and Branchiura. In: Margolis, L., Kabata, Z (eds.) Guide to the parasites of fishes of Canada. Part II - Crustacea. Can. Spec. Pub. Fish. Aquat. Sci. 101: 3-127

Kent, M. L., Hedrick, R. P. (1987). Effects of cortisol implants on the PKX myxosporean causing proliferative kidney disease in rainbow trout, Salmo gairdneri. J. Parasitol. 73: $455-461$

MacAurthur, J. L., Fletcher, T C., Pirie, B. J S., Davidson, R. J. L., Thompson, A. W. (1984). Peritoneal inflammatory cells in plaice, Pleuronectes platessa L.: effects of stress and endotoxin. J. Fish Biol. 25: 69-81

Maule, A. G., Schreck, C. B., Kaattari, S. L. (1987). Changes in the immune system of coho salmon (Oncorhynchus kisutch) during the parr-to-smolt transformation and after implantation of cortisol. Can. J. Fish. Aquat. Sci. 44: $161-166$

Nazrul Islam, A. K. M., Woo, P. T K. (1991). Trypanosoma danilewskyi in Carassius auratus: the nature of protective immunity in recovered goldfish. J. Parasitol. 77 : $258-262$

Pickering, A. D. (1987). Stress responses and disease resistance in farmed fish. In: Aqua Nor 87 Trondheim International Conference. Norske Fiskeoppdretternes Forening - Fiskeoppdrettones Salgslay A/L, Trondheim, Norway, p. 36-49

Pickering, A. D., Duston, J. (1983). Administration of cortisol to brown trout. Salmo trutta L. and its effects on the susceptibility to Saprolegnia infection and frunculosis. J. Fish Biol. 23: 163-175 
Pickering, A. D., Pottinger, T. G. (1985). Cortisol can increase the susceptibility of brown trout. Salmo trutta L., to disease without reducing the white blood cell count. J. Fish Biol. 27: 611-619

Roberts, R. J. (1978). Fish pathology. University Press, Aberdeen

Robertson, O. H., Hane, S., Wexler, B. C., Rintret, A. P. (1963). The effect of hydrocortisone on immature rainbow trout (Salmo gairdneri). Gen. comp. Endocrinol. 3: 422-436

Roubal, F. R., Bullock, A. M. (1988). The mechanism of wound reparr in the skin of juvenile Atlantic salmon, Salmo salar L., following hydrocortisone implantation. J. Fish Biol. 32: 545-555

Saad, A. H. (1988). Corticosteroids and immune systems of non-mammalian vertebrates: a review. Dev. comp. Immunol. 12: 481-494

Sumpter, J. P., Donaldson, E. M. (1986). The development and

Responsible Subject Editor: W. Körting, Hannover, Germany validation of a radioimmunoassay to measure plasma ACTH levels in salmonid fishes. Gen. comp. Endocrinol. 63: $367-376$

Weinreb, E. L. (1958). Studies on the histology and histopathology of the rainbow trout, Salmo gairdneri irideus. 1 Hematology: under normal and experimental conditions of inflammation. Zoologica, N.Y. 43: 145-154

Woo, P. T K., Leatherland, J. L., Lee, M. S. (1987). Cryptobia salmositica: cortisol increases the susceptibility of Salmo gairdneri Richardson to experimental cryptobiosis. J. Fish Dis. 10: $75-83$

Wootten, R., Smith, J W., Needham, E. A. (1982). Aspects of the biology of the parasitic copepods Lepeophtheirus salmonis and Caligus elongatus on farmed salmonids, and their treatment. Proc. R. Soc. Edinb. (Sect. B) 81: 185-197

Zar, J. H. (1984). Biostatistical analysis. Prentice Hall, Englewood Cliffs

Manuscript first received: May 12, 1992

Revised version accepted: August 8, 1992 